\title{
Medical Students' Knowledge about End-of-life Decision-Making
}

\author{
Conhecimento de Estudantes de Medicina \\ sobre Tomada de Decisão no Fim da Vida
}

\author{
Anielli Pinheiro \\ Marcelo Arruda Nakazone ${ }^{I}$ \\ Fernanda Silva Leal ${ }^{1}$ \\ Marcela Augusta Souza Pinhel \\ Dorotéia Rossi Silva Souza \\ José Paulo Cipullo
}

\author{
KEYWORDS: \\ - Bioethics \\ - Medical Ethics \\ - Medical Students \\ - Attitude towards Death \\ - Euthanasia
}

\section{PALAVRAS-CHAVE:}

- Bioética

- Ética Médica

- Estudantes de Medicina

- Atitude frente à Morte

- Eutanásia.

\section{Recebido em: 25/04/2010}

Reencaminhado em: 09/10/2010

Aprovado em: 20/10/2010
REVISTA BRASILEIRA DE EDUCAÇ̄̃o MÉDICA

\begin{abstract}
The influence of medical students' knowledge concerning end-of-life care, considering ethical theories and clinical practice, remains controversial. We aimed to investigate medical students' knowledge of bioethical concepts related to moral kinds of death (euthanasia, disthanasia, and orthothanasia) and to analyze the influence of their clinical experience on practicing such approaches in a tertiary hospital in the state of São Paulo, Brazil. We interviewed 180 medical students [distributed in Group 1 (G1) - first to third-year students, and Group 2 (G2) — fourth to sixth-year students] to evaluate the influence of the course on "medical ethics" on ethical theories and clinical practice, using a closed questionnaire. The course on "medical ethics" did not distinguish the groups $(P=0.704)$ in relation to bioethical concepts. Neologisms such as "cacothanasia" and "idiothanasia" were incorrectly viewed as bioethical concepts by $28 \%$ of the interviewees. Moreover, $45.3 \%$ of the sample considered health care professionals incapable of managing terminally ill patients, especially G2 (29\%) as compared to G1 (16.5\%, P=0.031). The concept of euthanasia was accepted by $41 \%$ of sample, as compared to $98.2 \%$ for orthothanasia. Among medical students that accepted ways to abbreviate life (22.9\%), 30.1\% belonged to G1, and only $16.1 \%$ to G2 (P=0.049). These medical students were unfamiliar with common bioethical concepts. Moreover, they considered healthcare professionals incapable of managing terminally ill patients. The ethical ideal of the "good death" reflects better acceptance of orthothanasia by medical students, suggesting a tendency to apply it in their future clinical practice.
\end{abstract}

\section{RESUMO}

A influência do conhecimento de estudantes de medicina sobre o manejo com o fim da vida, considerando teorias éticas e aplicabilidade clínica, permanece controversa. Objetivamos investigar o conhecimento de estudantes de medicina sobre conceitos bioéticos a respeito dos tipos morais de morte (Eutanásia, Distanásia e Ortotanásia) e analisar a influência de suas experiências clínicas para praticá-los, em um hospital terciário do estado de São Paulo, Brasil. Nós entrevistamos 180 estudantes de medicina [distribuídos em Grupo 1 (G1) — estudantes do primeiro ao terceiro ano de graduação em medicina e Grupo 2 (G2) - estudantes do quarto ao sexto ano] para avaliar a influência do "curso de ética médica" em teorias éticas e prática clínica, utilizando um questionário fechado. $O$ "curso de ética médica" não diferiu os grupos ( $P=0.704)$ sobre os conceitos bioéticos. Neologismos como Cacotanásia e Idiotanásia foram erroneamente considerados como conceitos bioéticos por $28 \%$ dos indivíduos. Além disso, $45.3 \%$ da amostra consideraram os profissionais de saúde inaptos ao manejo de pacientes terminais, principalmente G2 (29\%) comparado a G1 (16.5\%, $P=0.031$ ). O conceito de Eutanásia foi aceito por $41 \%$ da amostra, enquanto Ortotanásia por $98.2 \%$. Dentre os estudantes de medicina que aceitaram maneiras para abreviar a vida $(22.9 \%), 30.1 \%$ deles pertenciam a G1 enquanto somente $16.1 \%$ a $G 2(P=0.049)$. Estudantes de medicina mostram desconhecimento sobre conceitos clássicos em Bioética. Além disso, consideram os profissionais de saúde inaptos ao manejo de pacientes terminais. O ideal ético considerando a "boa morte" reflete melhor aceitação dos estudantes de medicina pela Ortotanásia, sugerindo tendência em aplicá-la em sua futura prática clínica. 


\section{INTRODUCTION}

Several goals have guided end-of-life medical decisions, considering the relief of suffering and improvement of quality of life for terminally ill patients and their families ${ }^{1-3}$. Substantial legal, ethical, and clinical consensus currently exists about end-of-life care, yet myths and misconceptions persist concerning what is ethically and legally permissible ${ }^{4}$. In this case, medical practice in relation to advanced and terminal illnesses remains controversial, although nearly 30 years have transpired since Karen Ann Quinlan's case, the first famous public discussion on end-of-life care ${ }^{5}$.

In this context, bioethical concepts were suggested in order to standardize medical practice concerning moral kinds of death. Euthanasia derives from the Greek (eu-thanatos) and literally means "good death". The term has come to refer to the effort to avoid prolonged and useless suffering, considering the relief of pain or other symptoms with a possible life-shortening effect ${ }^{6}$. In contrast, disthanasia (dis-thanatos, "death with difficulty") refers to futile treatment that prolongs the process of dying. In other words, it is medically futile that even with no expectation of cure, the treatment draws out the patient's agony $^{7}$. Between these two is orthothanasia (ortho-thanatos, "normal or natural death"), in reference to the natural process of dying after interruption of futile clinical treatment. These are controversial topics not only in the medical field but also in the social, political, philosophical, and religious domains ${ }^{8,9}$.

The debate on euthanasia and assisted suicide has grown remarkably in the last 20 years, attracting widespread attention by medical experts. Analyses on the moral classification of death are common in the literature, taking into account the opinions of health care professionals on bioethical values ${ }^{3,10-12}$. Medical schools in Brazil have included courses on medical ethics in the curriculum. Course objectives include increasing medical students' understanding of ethical terms and standards, as well as dilemmas in clinical settings ${ }^{13-16}$. Given the priorities in medical education, it is thus not surprising that medical students struggle to apply such ethical knowledge to clinical cases and sometimes confuse technical facts, personal or professional values, or clinical consensus with reasoned argument and justifiable clinical ethical decision-making ${ }^{17}$. Some recent studies have found that the curriculum can influence the students' ethical values during courses, considering the concurrent contact with clinical practice ${ }^{2,18}$.

In this context, the present study was designed to investigate the medical students' knowledge concerning bioethical concepts related to the moral classification of death (euthanasia, disthanasia, and orthothanasia) and to analyze the influence of their clinical experience in managing such types.

\section{METHODS}

A total of 180 medical students from the São José do Rio Preto School of Medicine participated (27 first-year, 26 second-year, 30 third and fourth-year, 27 fifth-year, and 30 sixth-year students). They were matched for gender and age. All individuals received a closed questionnaire, including 22 questions eliciting views on the moral classification of death and performance by health care professionals. Responses were returned anonymously by mail. The survey was conducted from July to September 2004. The study was approved by the Institutional Review Board of the School of Medicine in São José do Rio Preto, São Paulo State, Brazil (case review 302/2004). All subjects were informed in writing about the study, and all signed consent forms.

In Brazil, undergraduate medical school lasts six years, and students enter directly after high school. This medical school's fourth-year curriculum includes a short course on "medical ethics", consisting of lectures and discussions on bioethical concepts. A preliminary analysis considered the general responses by all the students. Next, the subjects were divided into two groups: Group 1 (G1), with first to third-year students, and Group 2 (G2), with fourth to sixth-year students, in order to evaluate the influence of the course on ethical theories in relation to their clinical practice.

Statistical analysis was performed comparing the groups in relation to gender and age using the t-test. Fisher's exact test was used for an exploratory analysis of medical students' knowledge concerning the moral classification of death, considering the absolute frequencies of the responses. Significance was set at $\mathrm{p}<0.05$.

\section{RESULTS}

Of the 180 individuals selected for the sample, 170 (94.4\%) responded. Ten medical students refused to participate. G1 did not differ statistically $(\mathrm{p}=0.704)$ from $\mathrm{G} 2$ in relation to total number of correct responses on bioethical concepts such as euthanasia, disthanasia, and orthothanasia (Table 1). Regarding the definition of euthanasia, sixth-year students showed a higher rate of correct answers (93.3\%). Meanwhile, fourth-year students showed better knowledge of disthanasia (73.3\%).

The analysis of lemmas involving treatment of terminally ill patients and moral classification of death showed that euthanasia was accepted by approximately $41 \%$ of medical students. However, 75\% (69\% in G1 and 80\% in G2) did not agree that euthanasia has been practiced by physicians in Brazil. Of the respondents, $7.7 \%$ accepted the use of drugs to relieve pain, but with a possible life-shortening effect, and $27.6 \%$ agreed with interruption of futile clinical treatment (Table 2). $98.2 \%$ of respondents were in favor of terminally ill patients 
TABle 1:

Medical students' views on bioethical concepts concerning moral classification of death

Bioethical concept

\begin{tabular}{|c|c|c|c|c|c|c|c|c|c|c|c|}
\hline \multicolumn{2}{|c|}{ Cacothanasia } & \multicolumn{2}{|c|}{ Disthanasia } & \multicolumn{2}{|c|}{ Euthanasia } & \multicolumn{2}{|c|}{ Idiothanasia } & \multicolumn{2}{|c|}{ Orthothanasia } & \multicolumn{2}{|c|}{ Blank } \\
\hline$n$ & $\%$ & $n$ & $\%$ & $n$ & $\%$ & $n$ & $\%$ & $n$ & $\%$ & $n$ & $\%$ \\
\hline 1 & 0.6 & 1 & 0.6 & 153 & 90.0 & 5 & 2.9 & 8 & 4.7 & 2 & 1.2 \\
\hline 9 & 5.3 & 111 & 65.3 & 1 & 0.6 & 6 & 3.5 & 34 & 20.0 & 9 & 5.3 \\
\hline 39 & 22.9 & 19 & 11.2 & 11 & 6.5 & 26 & 15.3 & 66 & 38.8 & 9 & 5.3 \\
\hline 62 & 36.5 & 21 & 12.4 & 4 & 2.3 & 54 & 31.8 & 17 & 10.0 & 12 & 7.0 \\
\hline 26 & 15.3 & 21 & 12.4 & 34 & 20.0 & 23 & 13.5 & 57 & 33.5 & 9 & 5.3 \\
\hline 15 & 8.8 & 19 & 11.2 & 57 & 33.5 & 20 & 11.8 & 50 & 29.4 & 9 & 5.3 \\
\hline
\end{tabular}

TABle 2:

Medical students' agreement with bioethical concepts and clinical practice

\begin{tabular}{|c|c|c|c|c|c|c|c|c|c|c|c|c|}
\hline \multirow[t]{2}{*}{ Question } & \multicolumn{2}{|c|}{ Totally agree } & \multicolumn{2}{|c|}{ Partially agree } & \multicolumn{2}{|c|}{$\begin{array}{l}\text { Neither agree } \\
\text { nor disagree }\end{array}$} & \multicolumn{2}{|c|}{$\begin{array}{l}\text { Partially } \\
\text { disagree }\end{array}$} & \multicolumn{2}{|c|}{$\begin{array}{l}\text { Totally } \\
\text { disagree }\end{array}$} & \multicolumn{2}{|c|}{ Blank } \\
\hline & $n$ & $\%$ & $n$ & $\%$ & $n$ & $\%$ & $n$ & $\%$ & $n$ & $\%$ & $n$ & $\%$ \\
\hline $\begin{array}{l}\text { "The administration of narcotics that causes two } \\
\text { distinct effects, relief of pain and shortening of } \\
\text { life, is legally permitted." }\end{array}$ & 13 & 7.7 & 80 & 47.0 & 23 & 13.5 & 32 & 18.8 & 20 & 11.8 & 2 & 1.2 \\
\hline $\begin{array}{l}\text { "Interrupting methods that prolong the process } \\
\text { of dying and avoiding useless suffering of } \\
\text { terminally ill patient are legally permitted." }\end{array}$ & 46 & 27.1 & 74 & 43.5 & 10 & 5.9 & 18 & 10.6 & 20 & 11.8 & 2 & 1.2 \\
\hline $\begin{array}{l}\text { "...euthanasia is a violation of Divine law, as a } \\
\text { deliberate and morally unacceptable death..." }\end{array}$ & 20 & 11.8 & 33 & 19.4 & 25 & 14.7 & 50 & 29.4 & 40 & 23.5 & 2 & 1.2 \\
\hline $\begin{array}{l}\text { "Considering their values and dignity, patients } \\
\text { may be treated with respect and, consequently, } \\
\text { they have the legal right to choose the } \\
\text { circumstances of their own death..." }\end{array}$ & 63 & 37.1 & 62 & 36.5 & 11 & 6.5 & 24 & 14.1 & 8 & 4.7 & 2 & 1.2 \\
\hline $\begin{array}{l}\text { "Everybody has the right to a dignified life, } \\
\text { so the patient has the legal right to choose to } \\
\text { die with dignity, even using a possibly life- } \\
\text { shortening method..." }\end{array}$ & 39 & 22.9 & 70 & 41.1 & 12 & 7.1 & 30 & 17.7 & 17 & 10.0 & 2 & 1.2 \\
\hline $\begin{array}{l}\text { "California law allows patients to decide not to } \\
\text { receive treatment that might sustain their life or } \\
\text { postpone death in a terminal situation..." }\end{array}$ & 46 & 27.1 & 69 & 40.6 & 25 & 14.7 & 22 & 12.9 & 6 & 3.5 & 2 & 1.2 \\
\hline $\begin{array}{l}\text { "Patients with incurable diseases have the right } \\
\text { to know their diagnosis." }\end{array}$ & 106 & 62.4 & 50 & 29.4 & 9 & 5.3 & 3 & 1.8 & 1 & 0.6 & 1 & 0.6 \\
\hline $\begin{array}{l}\text { "The physician has the responsibility to explain } \\
\text { to patients the real situation of their health } \\
\text { status..." }\end{array}$ & 85 & 50.0 & 60 & 35.3 & 14 & 8.2 & 8 & 4.7 & 2 & 1.2 & 1 & 0.6 \\
\hline
\end{tabular}

$n=$ number of answers 
TABLE 3:

Medical students' agreement with ethical theories and their use in clinical practice

\begin{tabular}{|c|c|c|c|c|c|c|}
\hline \multirow{2}{*}{ Question } & \multicolumn{2}{|c|}{ Yes } & \multicolumn{2}{|c|}{ No } & \multicolumn{2}{|c|}{ Blank } \\
\hline & $n$ & $\%$ & $n$ & $\%$ & $n$ & $\%$ \\
\hline $\begin{array}{l}\text { Do you consider physicians and other health care professionals capable of providing } \\
\text { adequate treatment and follow-up for terminally ill patients? }\end{array}$ & 90 & 52.9 & 77 & 45.3 & 3 & 1.8 \\
\hline $\begin{array}{l}\text { From the ethical point of view, does the physician or someone else have the responsibility } \\
\text { to practice euthanasia when they are asked to do so by a terminally ill patient in a free and } \\
\text { responsible manner? }\end{array}$ & 43 & 25.3 & 127 & 74.7 & 0 & 0 \\
\hline Can terminally ill patients die at home? & 167 & 98.2 & 3 & 1.8 & 0 & 0 \\
\hline Should human life be defended regardless of its quality? & 70 & 41.2 & 98 & 57.7 & 2 & 1.1 \\
\hline In Brazil, is it legal for a physician to practice euthanasia? & 4 & 2.3 & 166 & 97.7 & 0 & 0 \\
\hline Do you think a patient has the right to end his or her own life when in terminal condition? & 70 & 41.1 & 95 & 55.9 & 5 & 3.0 \\
\hline Do you practice any religion? & 156 & 91.8 & 13 & 7.6 & 1 & 0.6 \\
\hline If you practice a religion, did it influence your response to this questionnaire? & 65 & 38.2 & 100 & 58.8 & 5 & 3.0 \\
\hline
\end{tabular}

being allowed to die at home, and $2.3 \%$ were unaware of any illegal practice of euthanasia in Brazil.

Among the total sample of medical students, $22.9 \%$ agreed with ways of abbreviating life (30.1\% in G1 and only $16.1 \%$ in $\mathrm{G} 2$; $\mathrm{p}=0.049$ ). Moreover, $27 \%$ acknowledged the patient's right to instruct the physician on how to act in the case of a terminal condition. Sixty-two percent favored explaining patients' diagnosis to them, and 50\% considered this the physician's obligation. However, $45.3 \%$ of the sample $(16.5 \%$ in G1 and 29\% in G2, p=0.031; Table 3) considered physicians and other health care professionals unable to properly manage terminally ill patients.

Although $89 \%$ stated regularly practicing a religion, only fourth-year of the students felt that it influenced their end-of-life decisions. Among these, 55\% stated that euthanasia is a violation of Divine laws, while 19\% accepted the idea, despite not following any religious dogma.

\section{DISCUSSION}

The analysis of both groups of medical students' bioethical knowledge on moral kinds of death showed their unfamiliarity with the common concepts of euthanasia, disthanasia, and orthothanasia ${ }^{19-21}$. The high frequency of responses concerning the neologisms "cacothanasia" and "idiothanasia" as authentic bioethical terms confirms that short courses in medical ethics do not suffice to orient qualified future professionals in clinical settings, even in a university hospital ${ }^{9}$. This highlights the importance of organizing the curriculum towards better integration between learning and medical practice ${ }^{17,22}$, considering the laws in force in Brazil.
The process of dying is not always self-evident in clinical practice. The Terri Schiavo case reveals the controversy and unfamiliarity of moral kinds of death and their actual definitions and legal parameters ${ }^{24}$. Some students in this study had difficulty distinguishing between ethical and social issues, particularly those involving justice and health care allocation ${ }^{25}$. The important task of devising teaching strategies to assist students in integrating their ethical knowledge and enabling them to systematically analyze and manage ethical aspects in clinical practice is still necessary ${ }^{17,21}$. In this context, the discussion on euthanasia and futile medical treatment ${ }^{26}$ reveals medical students' insecurity towards end-of-life care.

The higher level of acceptance of euthanasia among first to third-year medical students as compared to fourth to sixth-year students confirms that their ethical reasoning skills change over time, considering the ability to recognize and assess the ethical problems found in clinical practice ${ }^{2,18,27}$. This suggests that contact with terminally ill patients reduces the acceptance of euthanasia. Similar situations have been observed in surveys that included lawyers, social sciences students, or engineers along with physicians and health care professionals ${ }^{12,28}$.

In our series, most respondents felt that patients should have knowledge regarding their terminal condition, and that attending physicians should explain their perspective, even though they considered them unprepared for this ethical attitude and for proper clinical management of terminally ill patients $^{9,21,22}$. In this context, one important aspect of providing better care for dying patients is to understand their symptoms and concerns, with a view towards better communication in 
the physician-patient relationship ${ }^{4,29}$. This suggests that discussing topics related to death and dying may actually be helpful for many terminally ill patients who are unable to accept their own death, while allaying their related fears and anxiety ${ }^{30}$.

Our data suggest that religious affiliation does not directly influence medical students' ethical reasoning on moral classification of death. In this case, half of the respondents stated that religious dogmas had not determined their ethical positions, corroborating Ramírez-Rivera et al. ${ }^{31}$ and Cohen et al. ${ }^{32}$. The latter authors concluded that guidance by religious institutions has some influence on end-of-life decision-making but is certainly not blindly accepted by physicians. Most people allow adaptations to particular situations, for instance to the needs and wishes of the dying and considerations of humaneness ${ }^{3}$.

In short, these medical students proved to be unfamiliar with common bioethical concepts. Moreover, they considered health care professionals unable to manage terminally ill patients. However, the ethical ideal of the "good death" appears to better reflect the acceptance of orthothanasia, suggesting a tendency to apply it to their future clinical practice.

\section{Acknowledgements}

The authors wish to thank the São Paulo State Medical Board (Conselho Regional de Medicina do Estado de São Paulo - CREMESP) for providing A. Pinheiro with a scholarship (under the program to support scientific research in medical ethics) in 2004.

\section{REFERENCES}

1. Marco CA. Ethical issues of resuscitation: an American perspective. Postgrad Med J 2005; 81 (959): 608-612.

2. Akabayashi A, Slingsby BT, Nagao N, Kai I, Sato H. An eight-year follow-up national study of medical school and general hospital ethics committees in Japan. BMC Med Ethics 2007; 8: 8.

3. Löfmark R, Nilstun T, Cartwright C, Fischer S, van der Heide A, Mortier F, et al. Physicians' experiences with end-of-life decision-making: survey in 6 European countries and Australia. BMC Med 2008; 6: 4.

4. Snyder L, Leffler C; Ethics and Human Rights Committee, American College of Physicians. Ethics manual: fifth edition. Ann Intern Med 2005; 142 (7): 560-582.

5. Meisel A, Snyder L, Quill T; American College of Physicians--American Society of Internal Medicine End-of-Life Care Consensus Panel. Seven legal barriers to end-of-life care: myths, realities, and grains of truth. JAMA 2000; 284 (19): 2495-2501.
6. Sklansky M. Neonatal euthanasia: moral considerations and criminal liability. J Med Ethics 2001; 27 (1): 5-11.

7. Chao DVK, Chan NY, Chan WY. Euthanasia revisited. Fam Pract 2002; 19 (2): 128-134.

8. Grassi L, Magnani K, Ercolani M. Attitudes toward euthanasia and physician-assisted suicide among Italian primary care physicians. J Pain Symptom Manage 1999; 17 (3): 188-196.

9. Vilela LP, Caramelli P. Knowledge of the definition of euthanasia: study with doctors and caregivers of Alzheimer's disease patients. Rev Assoc Med Bras 2009; 55 (3): 263-267.

10. Groenewoud JH, van der Maas PJ, van der Wal G, Hengeveld MW, Tholen AJ, Schudel WJ, et al. Physician-assisted death in psychiatric practice in the Netherlands. N Engl J Med 1997; 336 (25): 1795-1801.

11. Meier DE, Emmons CA, Wallenstein S, Quill T, Morrison RS, Cassel CK. A national survey of physician-assisted suicide and euthanasia in the United States. N Engl J Med 1998; 338 (17): 1193-1201.

12. Fekete S, Osvath P, Jegesy A. Attitudes of Hungarian students and nurses to physician assisted suicide. J Med Ethics 2002; 28 (2): 126.

13. Gomes AM, Moura ER, Amorim RF. O lugar da ética e bioética nos currículos de formação médica. Rev Bras Educ Méd 2006; 30 (2): 56-65.

14. Almeida AM, Bitencourt AG, Neves MN, Neves FB, Lordelo MR, Lemos KM, et. Conhecimento e interesse em ética médica e bioética na graduação médica. Rev Bras Educ Méd 2008; 32 (4): 437-444.

15. Dantas F, Sousa EG. Ensino da deontologia, ética médica e bioética nas escolas médicas brasileiras: uma revisão sistemática. Rev Bras Educ Méd 2008; 32 (4): 507-517.

16. Silva RP, Ribeiro VM. Rev Bras Educ Méd 2009; 33 (1): 134-143.

17. Myser C, Kerridge IH, Mitchell KR. Teaching clinical ethics as a professional skill: bridging the gap between knowledge about ethics and its use in clinical practice. J Med Ethics 1995; 21 (2): 97-103.

18. Marini MC, Neuenschwander H, Stiefel F. Attitudes toward euthanasia and physician assisted suicide: a survey among medical students, oncology clinicians, and palliative care specialists. Palliat Support Care 2006; 4 (3): 251-255.

19. Hernández-Arriaga JL, Morales-Estrada A, Cortés Gallo G. Survey of physicians' attitudes to terminal patients. Rev Invest Clin 1997; 49 (6): 497-500.

20. Cataldo NA, Araújo PA. A morte e o morrer no hospital escola. Rev Bras Educ Méd 1996; 20 (esp): 26-28.

21. Marta GN, Marta SN, Filho AA, Job JR. O estudante de medicina e o medico recém-formado frente à morte e ao morrer. Rev Bras Educ Méd 2009; 33 (3): 416-427. 
22. Ramírez-Rivera J, Ramos O. Euthanasia and relief of suffering: attitudes of medical students. Bol Asoc Med P R 1995; 87 (10-12): 164-166.

23. Falcão EB, Mendonça SB. Formação médica, ciência e atendimento ao paciente que morre: uma herança em questão. Rev Bras Educ Méd 2009; 33 (3): 364-373.

24. Koch T. The challenge of Terri Schiavo: lessons for bioethics. J Med Ethics 2005; 31 (7): 376-378.

25. Beauchamp TL, Childress JF. Principles of biomedical ethics [3rd Ed]. New York: Oxford University Press, 1989.

26. Kasman DL. When is medical treatment futile? A guide for students, residents, and physicians. J Gen Intern Med 2004; 19 (10): 1053-1056.

27. Gruber PC, Gomersall CD, Joynt GM, Lee A, Tang PY, Young AS, et al. Changes in medical students' attitudes towards end-of-life decisions across different years of medical training. J Gen Intern Med 2008; 23 (10): 1608-1614.

28. Ramírez-Rivera J, Rodríguez R, Otero Igaravidez Y. Attitudes toward euthanasia, assisted suicide and termination of life-sustaining treatment of Puerto Rican medical students, medical residents, and faculty. Bol Asoc Med P R 2000; 92 (1-3): 18-21.

29. Emanuel EJ, Emanuel LL. The promise of a good death. Lancet 1998; 351(suppl): S21-S29.

30. Emanuel EJ, Fairclough DL, Wolfe P, Emanuel LL. Talking with terminally ill patients and their caregivers about death, dying, and bereavement: is it stressful? Is it helpful? Arch Intern Med 2004; 164 (18): 1999-2004.

31. Ramírez-Rivera J, Cruz J, Jaume-Anselmi F. Euthanasia, assisted suicide and end-of-life care: attitudes of students, residents and attending physicians. P R Health Sci J 2006; 25 (4): 325-329.
32. Cohen J, van Delden J, Mortier F, Löfmark R, Norup M, Cartwright $\mathrm{C}$, et al. Influence of physicians' life stances on attitudes to end-of-life decisions and actual end-of-life decision-making in six countries. J Med Ethics 2008; 34 (4): 247-253.

\section{AUTHORS' CONTRIBUTIONS}

Anielli Pinheiro contributed to the planning of the research, data collection and analysis, discussion of the results, and writing of the article. Marcelo A. Nakazone contributed to the planning of the research, analysis and discussion of the results, and writing of the article. Fernanda S. Leal contributed to the planning of the research, data collection, and analysis of the results. Marcela A. S. Pinhel and Dorotéia R.S. Souza contributed to the analysis of the results and writing of the article. José P. Cipullo contributed with the research planning and coordination and discussion of the results.

\section{CONFLICTS OF INTEREST}

The authors had no conflicts of interest.

\section{ADDRESS FOR CORRESPONDENCE}

Anielli Pinheiro

Departamento de Biologia Molecular

Núcleo de Pesquisa em Bioquímica e Biologia Molecular Faculdade de Medicina de São José do Rio Preto

Av. Brigadeiro Faria Lima, 5416

Bairro - São José do Rio Preto

CEP. 1509000 SP, Brasil.

E-mail: anielli.pinheiro@yahoo.com 